\title{
AN ANALYSIS OF TAQWA IN THE HOLY QURAN: SURAH AL- BAQARAH
}

\author{
Harison Mohd. Sidek ${ }^{1 *}$, Sulaiman Ismail ${ }^{2}$, Noor Saazai Mat Said ${ }^{3}$, Fariza Puteh \\ Behak $^{4}$, Hazleena Baharun ${ }^{5}$, Sulhah Ramli ${ }^{6}$, Mohd Aizuddin Abd Aziz ${ }^{7}$, Noor Azizi \\ Ismail $^{8}$, Suraini Mat $\mathrm{Ali}^{9}$
}

\footnotetext{
${ }^{1}$ Associate Professor Dr., Universiti Sains Islam Malaysia, MALAYSIA, harison@usim.edu.my

${ }^{2}$ Mr., Universiti Sains Islam Malaysia, MALAYSIA, sulaiman@usim.edu.my

${ }^{3}$ Dr., Universiti Sains Islam Malaysia, MALAYSIA, noorsaazai@usim.edu.my

${ }^{4}$ Dr., Universiti Sains Islam Malaysia, MALAYSIA, fariza@usim.edu.my

${ }^{5}$ Dr., Universiti Sains Islam Malaysia, MALAYSIA, hazleena@usim.edu.my

${ }^{6}$ Ms., Universiti Sains Islam Malaysia, MALAYSIA, sulhah@usim.edu.my

${ }^{7}$ Mr., Universiti Sains Islam Malaysia, MALAYSIA, aizuddin@usim.edu.my

${ }^{8}$ Associate Professor Dr., Universiti Sains Islam Malaysia, MALAYSIA, azizi12@usim.edu.my

${ }^{9}$ Dr., Universiti Sains Islam Malaysia, MALAYSIA, suraini@usim.edu.my

${ }^{*}$ Corresponding author
}

\begin{abstract}
Within the context of the Islamic religion, having Taqwa or the traits of righteousness is imperative because Taqwa reflects the level of a Muslim's faith. Hence, the purpose of the present study was to identify the traits of Takwa in surah Al-Baqara in the Holy Quran. The data for this study were obtained from verses in surah Al-Baqara. Purposive sampling was used to select the verses that contain the traits of Taqwa using an established tafseer (Quranic interpretation) in the Qurainic field as a guideline in marking the Taqwa traits in sampling the verses. Two experts in the field of Quranic tafseer validated the traits of Taqwa extracted from each selected verse. The data were analyzed using manifest and latent content analyses. The findings reveal 10 categories of traits of Taqwa which are tawheed or monotheism, do good to others, performing solah, paying of zakat, honouring rights, repentance, doing good deeds, righteous communication, being grateful, being sincere, and recognition of the absoluteness of Allah's sovereignty. Sequential emphasisbased analysis was used to tabulate the reiteration of each trait of Taqwa in order to find out the trait that is most frequently emphasized in the form of reiteration. Among the Taqwa category traits, the major emphasis is on tawheed or believing the oneness of Allah. The findings help in enhancing the understanding and the meta-framework of the traits of Taqwa, which is particularly useful for non-scholarly Muslims in strengthening their Islamic faith in accordance to what is commanded in the Holy Quran.
\end{abstract}

Keywords: Taqwa, Al-Baqarah, Traits, Thematic Analysis, Sequential-Based Analysis, Quran. 


\section{INTRODUCTION}

The term 'muttaqin', which means those of Taqwa is mentioned in the second verse of surah Al-Baqara. In this verse, Allah SWT dedicates the Holy Quran to the Muslims hailed as 'muttaqin'. The term Taqwa in the Holy Quran is used in various conjugated forms or in different forms of speech depending on the relevant proposition of Takwa. The importance of Taqwa can be seen, for instance, in Islamic Friday sermons on every Friday in which it is mandatory for the khatib or the preacher to call and remind the Muslim to be among the 'muttaqin'. Such a commandment from Allah SWT suggests the importance of Muslims to attain Taqwa in order to have a true faith as Muslims. Hence, Taqwa is considered as one of the important, recurring, and dominant elements in the Quranic verses. Taken these into account, Taqwa remains as one of the fundamentals of Islamic faith. Considering the importance of Taqwa, it is therefore, imperative to analyze what traits that Taqwa entails, so that the Muslims have a better understanding of what traits need to be nurtured in order to achieve Taqwa. Nonetheless, specific studies manifesting the framework of Taqwa in a way that the elements of Taqwa can be presented in a directly explicit manner are rather scarce or almost non-existent. If such studies had been conducted, they might not be included in the mainstream journals. The lack of empirical studies on Taqwa could be perhaps due to the abundant of discussion of Taqwa (AlAtrash, 2002; Amar 'Abdullah al-Muqbil, 2010; Al-sheikh; Muhammad Syamsuddin al-Qurtubiy, 2003; AlGhazali, 2004; Ali, 1997; Al-Sharawi, 2004), nonetheless in a rather scattered manner. As such, the current study attempted to analyze the traits of Taqwa in the Quran in order to produce a more explicit framework of Taqwa, which can be useful to all Muslims, particularly the non-scholars or laymen believers. As a preliminary investigation, the present study focused on the analysis of the elements of Taqwa in the first half of Surah Al-Baqara.

\subsection{Methodology}

The purposes of the present study were to identify the traits of taqwa from Surah Al-Baqara as well as to analyze the different degree of emphasis on each trait. The study sought to answer the following research questions (RQ):

$R Q$ 1: What are the traits of Taqwa reflected in verses 1 to143 in Surah Al-Baqarah in the Holy Quran? $\mathrm{RQ} 2$ : What is the major emphasis of the traits of Taqwa reflected in verses 1 to143 in surah Al-Baqarah in the Holy Quran?

\subsubsection{Instrument and Sampling}

The current study is a pilot study that analyzed the traits of Taqwa in surah Al-Baqara in the Holy Quran. Therefore, the Holy Quran was the instrument used to obtain the data in this study. There are 286 verses in surah Al-Baqara. Since this study is a pioneering study, surah Al-Baqara was purposively selected since it is the first surah after surah Al-Fatihah in the Holy Quran. Surah Al-Fatihah, which has seven verses was not analyzed because the term 'muttaqin' is only explicitly mentioned beginning from verse 2 in surah Al-Baqara. In general, the concept of Taqwa is manifested in Quranic chapters revealed in Mecca. Nonetheless, chapters in the Quran revealed in the city of Medina also contain the concept of Taqwa.

\subsubsection{Data Collection}

In this study, the concept of Taqwa literally focuses on its explicit conceptual elements within the context of Islam. Hence, within the context of this study, the term 'Taqwa' was defined as traits of righteousness or good deeds, which traits Allah SWT commands a believer to have. In identifying the traits of Taqwa in the selected surah, each verse from verses 1-143 was reviewed. Due to the limited scope of this paper, only 143 verses, which are $50 \%$ of the total verses in the selected surah were reviewed. Out of the 143 verses, only verses that contain traits of Taqwa were selected as the sampling for this study. For example, Surah Al Baqara verse 3 was inferred to contain 3 traits of Takwa:

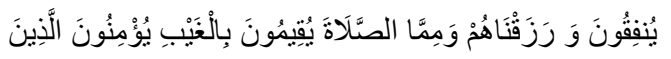

Those who believe in the unseen and keep up prayer and spend out of what We have given them

Therefore verse 3 of Surah Al Baqarah was selected. All verses in the selected surah that were inferred to comprise traits of Taqwa were selected as the samples for this study while verses that do not contain traits of Taqwa were excluded. Eleven verses of Surah Al-Baqara were selected as the sample verses for the current study. Verses that do not contain any command on traits that man should have were excluded during the verses sampling selection procedure. 


\subsubsection{Data Analysis}

The data in this study were analyzed using latent and manifest content analysis for Research Question 1 and 2 respectively. Since the current study solely involved document analysis to make inferences, content analysis was used as the method of data analysis. Therefore, content analysis can be a useful tool for examining trends and patterns in documents (Stemler, 2001; Sidek, 2010).

To answer Research Question 1, the traits of Taqwa were extracted from each selected verse. Within the context of this study, traits of Taqwa are defined as behavior or belief commanded by Allah S.W.T. For example, in verse 3 of Surah Al Baqara, 3 Taqwa traits were identified as shown below:

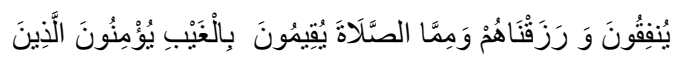

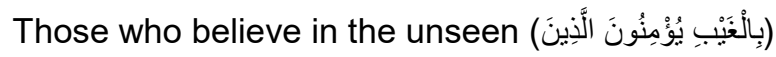

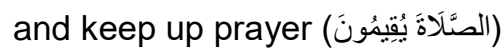

and spend out of what We have given them (يُنَفِقُنَ وَ رَزَفْنَاهُمْ وَمِمًَا)

To answer the first research question, latent content analysis was conducted. Latent content analysis was used to analyze the data in this study because the present study is a qualitative study in nature. Latent analysis was conducted via thematic analysis by coding the extracted traits of Taqwa thematically in order to identify the category of traits of Taqwa. Thematic coding is a qualitative analytic method for "identifying, analyzing and reporting pattern (themes) within data. It minimally organizes and describes your data set in (rich) detail. However, it frequently goes further than this, and interprets various aspects of the research topic," (Braun \& Clarke, 2006, p.79).

To answer Research Question 2, manifest content analysis was conducted. According to Basturkmen (1999, p. 21), "Content analysis is widely used in historical and communication research. It involves the analysis of the content of communication (documents) as the basis for inference."

In this study, the frequency of each trait of Taqwa in each category was counted and converted into percentages. The categories of traits of Taqwa were ranked according to the percentages in an ascending manner to determine the emphasis of traits of Taqwa in the selected Surahs. By following this technique, we can analyze the emphasis of the traits of Taqwa in the selected surah.

\subsubsection{Validity Procedure}

Two stages of validity procedure were conducted. The first stage of validity procedure was conducted by an expert who rated the selected verses using a Likert scale indicating his agreement if the selected verses contain the traits of taqwa. The validity index is 0.9 . The second stage of validity procedure was on the traits of Taqwa inferred in the selected verses. This validity procedure was also conducted by an expert who compared the inferred traits against the interpretation of the selected verses in the selected source of tafseer (Ibn Kathir; Al-Jalalyn). The validity index of the inferred traits of taqwa against the selected tafseer is also 0.9. This validity index shows that the translations of these Quranic verses follow the works of Ibn Kathir and Al-Jalalyn. As generally accepted by the scholars in the field of Quranic tafseer, the ways in which tafseer is navigated by Al-Jalalyn can be used as a point of reference, therefore, useful in this study.

\section{FINDINGS}

It is imperative to reiterate that the findings of the analysis of taqwa presented in this study are derived from the sampling from the first $50 \%$ of surah al-Baqara or from verses 1 to 143 .

Traits of Takwa

$\mathrm{RQ}$ 1: What are the traits of Taqwa reflected in verses 1 to 143 in Surah Al-Baqara in the Holy Quran?

Table 1 presents the traits of Taqwa in surah AI-Baqara. There are 6 verses in Surah Al-Baqara that contain 19 traits of Taqwa in total in this surah.

\section{Table 1: Traits of Taqwain Surah Al-Baqara}

\begin{tabular}{|l|l|l|c|}
\hline No & \multicolumn{1}{|c|}{ Al Baqara verse } & \multicolumn{1}{c|}{ Traits of Taqwa(ToT) } & ToT per Verse \\
\hline 1 & Verse 3 & $\begin{array}{l}\text { (ToT1) Those who believe in the unseen } \\
\text { (ToT2) and keep up prayer } \\
\text { (ToT3) and spend out of what We have } \\
\text { given them }\end{array}$ & 3 \\
\hline 2 & Verse 4 & $\begin{array}{l}\text { (ToT4) And who believe in that which has } \\
\text { been revealed to you }\end{array}$ & \\
\hline
\end{tabular}




\begin{tabular}{|c|c|c|c|}
\hline & & $\begin{array}{l}\text { (ToT5) and that which was revealed before } \\
\text { you } \\
\text { (ToT6) and they are sure of the hereafter }\end{array}$ & 3 \\
\hline 3 & Verse 21 & $\begin{array}{l}\text { (ToT7) serve your Lord Who created you } \\
\text { and those before you }\end{array}$ & 1 \\
\hline 4 & Verse 82 & $\begin{array}{l}\text { (ToT8) those who believe } \\
\text { (ToT9) and do good deeds }\end{array}$ & 2 \\
\hline 5 & Verse 83 & $\begin{array}{l}\text { (ToT10) You shall not serve any but Allah } \\
\text { (ToT11) and (you shall do) good to (your) } \\
\text { parents } \\
\text { (ToT12) and to the near of kin } \\
\text { (ToT13) and to the orphans } \\
\text { (ToT14) and the needy } \\
\text { (ToT15) and you shall speak to men good } \\
\text { words } \\
\text { (ToT16) and keep up prayer } \\
\text { (ToT17) and pay the poor-rate }\end{array}$ & 8 \\
\hline 6 & Verse 84 & $\begin{array}{l}\text { (ToT18) You shall not shed your blood } \\
\text { (ToT19) and you shall not turn your people } \\
\text { out of your cities }\end{array}$ & 2 \\
\hline 7 & Verse 110 & $\begin{array}{l}\text { (ToT20) And establish prayer... } \\
\text { (ToT21)...and give zakah }\end{array}$ & 2 \\
\hline 8 & Verse 122 & $\begin{array}{l}\text { (ToT22)... remember my favour which I have } \\
\text { bestowed upon you }\end{array}$ & 1 \\
\hline 9 & Verse 136 & $\begin{array}{l}\text { (ToT23) Say, "We have believed... and we } \\
\text { are Muslims in submission to Him" }\end{array}$ & \\
\hline 10 & Verse 139 & $\begin{array}{l}\text { (ToT24) Say, "...And we are sincere in deed } \\
\text { and intention to Him.” }\end{array}$ & 1 \\
\hline 11 & Verse 142 & $\begin{array}{l}\text { (ToT25) Say, To Allah belongs the east and } \\
\text { the west." }\end{array}$ & 1 \\
\hline
\end{tabular}

From the table above, the number of ToT varies. The ToT begins to be presented in verse 3 of this surah with a sequence; the first ToT is Tawheed, followed by Solah and Charity. In the next verse, which is verse 4, Allah SWT elaborates the ToT of Tawheed to include the belief in what has been brought down to Rasullulah (pbuh) as well as what was brought down prior to Rasulullah's (pbuh) time. In addition, in the same verse, a new ToT of believing in the hereafter is introduced. After verse 4, with a gap of 17 verses, the presentation of $\mathrm{ToT}^{\mathrm{B}}$ appears again in verse 21 repeating the Tawheed. Next, in verse 82 , after a gap of 61 verses, Allah SWT repeats the ToT $^{\mathrm{B}}$ of Tawheed followed by the mentioning of doing good deeds in general.

The ToT of Tawheed continues to appear in the subsequent verse 83. In verse 83, the ToT of Tawheed is reemphasized prior to the command of 7 ToT; to do good to parents, next of kin, orphans and needy as well as to speak good words to man. The ToT of performing solah and doing charity commanded in verse 3 are reemphasized in verse 83 . Two new ToT are introduced in verse 84 related to human's right in which Allah commands man to avoid killing and invasion of one's territory. In Surah Al-Baqara, Allah SWT repeats the ToT of Tawheed four times in comparison to other ToT while Solah and Charity are repeated twice. The rest of ToT are only mentioned once in this surah. In sum, the findings can be concluded that among the ToT that one should have to be a muttaqun are firstly Tawheed (aqidah), Solah, Charity, good relationship with other people especially parents, the poor and the needy as well as respecting human's rights in terms of killing and territory invasion.

\section{Emphasis on Traits of Takwa}

$\mathrm{RQ} 2$ : What is the emphasis on each of the traits of Taqwa reflected in verse 1 to143 in Surah Al-Baqara in the Holy Quran?

The traits of Taqwa extracted in the selected verses were analyzed thematically. The analysis generated 11 frequency-based sequential categories of traits of Taqwa

The above findings are summarized in terms of the rates and ranking of reiteration for each of the ToT. 
IJASOS- International E-Journal of Advances in Social Sciences, Vol. III, Issue 8, August 2017

Table 2: Sequential Emphasis-Based Analysis of Traits of Taqwa (ToT ${ }^{\mathrm{Tw}}$ )

\begin{tabular}{|l|c|c|}
\hline \multicolumn{1}{|c|}{ Traits of Takwa } & $\begin{array}{c}\text { Rates of } \\
\text { Reiteration (\%) }\end{array}$ & $\begin{array}{c}\text { Rank of } \\
\text { Reiteration }\end{array}$ \\
\hline Believe in the oneness of Allah (Tawheed) & 25.0 & 1 \\
\hline Do Good to Others & 16.7 & 2 \\
\hline Performing solah & 12.5 & 3 \\
\hline Paying Zakat/charity/alms & 12.5 & 3 \\
\hline Honouring rights & 8.3 & 4 \\
\hline Repentance (Tawbah) & 4.1 & 5 \\
\hline Do Good deeds & 4.1 & 5 \\
\hline Ma'aruf (righteous) Communication & 4.1 & 5 \\
\hline Being grateful & 4.1 & 5 \\
\hline Being sincere & 4.1 & 5 \\
\hline Recognition of Allah's absoluteness in sovereignty & 4.1 & 5 \\
\hline
\end{tabular}

Table 2 presents the 5 ranks of emphasis of the traits of Takwa. Tawheed is first in rank, followed by Doing Good to Others, being second in rank. Performing solah and paying zakat are equally reiterated in the third rank of ToT. Honouring rights ranks fourth while Repentance (Tawbah), Do Good Deeds, Ma'aruf (righteous) Communication, being grateful, being sincere \& Recognition of Allah's Absoluteness in Sovereignty follow up in the fifth rank.

\section{DISCUSSION}

The findings show that there are 23 ToTs mentioned in the selected verses in Surahs Al-Baqara, namely Believe in Allah/Tawheed (ToT $\left.{ }^{\mathrm{TW}}\right)$, performing solah(ToT $\left.{ }^{\mathrm{PS}}\right)$, zakat or tithe/charity/alms $\left(\mathrm{ToT}^{\mathrm{C} / \mathrm{A}}\right)$, do good to others (ToT ${ }^{\mathrm{DGO}}$ ), do good deeds (ToT ${ }^{\mathrm{GD}}$ ), ma'aruf communication (ToT ${ }^{\mathrm{MC}}$ ), honour human's rights (ToT ${ }^{\mathrm{HR}}$ ), being grateful, being sincere and Recognition of Allah's Absoluteness in Sovereignty. The term muttaqin is mentioned in the second verse of surah Al-Baqara and followed by the descriptions of the muttaqin as those who believe in the unseen, performing solah and those who pay the poor rate and the mentioning of the other traits of muttaqin in the selected verses. It is important to note that when analyzing the Quranic verses, literal classification is not tangible because the Quran is unique in its own way in terms of its arrangement and presentation. Such a condition is similar when determining the traits of taqwa in the current study. Hence, what can be laid out is what is mentioned either literally or by tafseer. Nonetheless, based on the analysis in this study, Tawheed is the primary condition of being a muttaqun (a person of taqwa). Having the other traits without having Tawheed does not translate to taqwa as in the case on non-believers regardless of them implementing the other ToTs. For example, a non-believer who practices all ToTs, but with the absence of Tawheed is not considered as a muttaqun.

In terms of emphasis on the traits of takwa, the findings in this study show that Tawheed is the most frequently mentioned ToT (Rank 1), a trait that is required for one to qualify for takwa. Tawheed is also most frequently mentioned in the first half of surah Al-Baqara. Within the context of this study, although Solah is mentioned immediately after Tawheed in Verse 2, surah Al-Baqara, it appears in the third rank together with the ToT of Doing Good to Others. This finding needs further analysis of why it comes in such a sequence in terms of emphasis in the form of reiteration. Instead, Doing Good to Others comes second in rank after the pre-condition of having Tawheed. This finding suggests that Islam is a religion of peace, of which it advocates good relationship with others at all times. In fact, the verses that reflect this ToT does not come with any specification that the Muslims should do good only to the Muslims. Such revelation reflects the generally known trait of Allah as Ar-Rahman, which means the Most Merciful to all His creations in the entire universe. The emphasis on doing good to others is followed by the Honouring Rights ToT in the fourth rank. In order to do good to others, one needs to honour the rights of others. By emphasizing the ToT of Doing Good to Others as the 'what to do', the ToT of Honouring rights comes next in sequence as the explanation of the 'How to do'. These findings demonstrate such a neat sequence of the ToT meta-framework.

The rest of the ToTs within the context of this study, Repentance (Tawbah), Do Good deeds, Ma'aruf Communication, being grateful, being sincere \& Recognition of Allah's Absoluteness in Sovereignty, which are listed in the last rank are of no less importance. Although they are reiterated once in the first half of surah al Baqara, it is premature to underestimate their importance since the current study only analyzed the first half of al Baqara due to the limitation of the scope of this paper. The fact that these ToTs are mentioned in the revelation of the first half of surah al Baqara, should indicate that these ToTs are to be considered as of no less importance to be practiced by the Muslims. 


\section{CONCLUSION}

The purposes of the study were to identify the traits of Taqwa and to analyze the emphasis of the traits of Taqwa as presented in Surah Al-Baqara. The findings of this preliminary study show that there are 11 traits of Taqwa mentioned in the selected surah with each trait given a different emphasis. By explicitly knowing the TOTs, it helps in providing the Muslims with a better understanding of what Taqwa entails and such understanding can serve as a general guidance in the Muslims' effort to achieve Taqwa and be among the muttaqin as mentioned in the Holy Quran.

Note: This study was funded by Universiti Sains Islam Malaysia (PPP/USG-0116/FPBU/30/12216).

\section{REFERENCE LIST}

Ali, A. Y. (1997). The Meaning of the Quran. Maryland: Amana publications.

Al-Atrash (2002). Hakekat Al-Taqwa. Alexandria: Dar-Aliman.

Al-Ghazali, M. (2004). Khuluk Al Muslim. Damascus: Dar Alkalam.

'Amar 'Abdullah al-Muqbil (2010). Kaedah: Fasalu ahl al-Dhikr In Kuntum la Ta'lamun. Accessed on 4 September 2013 from http://almoslim.net/node/126966 website.

Braun, V. \& Clarke, V. (2006). Using thematic analysis in psychology. Qualitative Research in Psychology, 3 , 77-101.

Ibn Kather, A-Q. A-D. A. I. (2000). Tafsir (commentary) Ibn Kather. Riyadh: Darussalam Publishers \& Distributions.

Isma'il Kathir al-Dimasyqiy (2000). Tafsir al-Qur’an al-'Azim. Kaherah: Muassasat Qurtabat.

Muhammad al-Tahir 'Asyur (2000). al-Tahrir wa al-Tanwir, Jld. 26. Beirut: Muassasat al-Tarikh al-'Arabiy.

Muhammad al-Syanqitiy (1995). Adwa' al-Bayan Fi ldat al-Qur'an bi al-Qur'an, Jld. 6. Beirut: Dar al-Fikr.

Muhammad Syamsuddin al-Qurtubiy (2003). al-Jami' li al-Ahkam al-Qur'an. Riyadh: Dar al-'Alam al-Kutub.

Muhammad Taqi-ud-Din al-Hilali \& Muhammad Muhsin Khan. (1984). The Noble Quran: English Translation of the Meanings and Commentary. King Fahd Complex.

Sabitha Marican (2006). Penyelidikan Sains Sosial - Pendekatan Pragmatik. Selangor: Edusystem Sdn. Bhd.

Sidek, H.M. (2010). An Analysis of EFL Curriculum in Malaysia: Approaches to Reading and Preparation for Higher Education. PhD Thesis. University of Pittsburgh.

Stemler, S. (2001). An overview of content analysis. Practical assessment, Research and Evaluation, 7 (17).

Tafsir al-Jalalayn (2013). trans. Feras Hamza. Royal Aal al-Bayt Institute for Islamic Thought, Amman, Jordan http://www.aalalbayt.org, http://www.altafsir.com 